\author{
ANDRZEJ DERDZIUK \\ Katolicki Uniwersytet Lubelski Jana Pawła II \\ Wydział Teologii
}

\title{
Tajemnica spowiedzi świętej
}

\section{A Secret of Confession}

W sakramencie pokuty i pojednania człowiek spotyka się z Bogiem i otwiera serce na dar przebaczenia i odnowienia swego życia. Zachowując wiarę w zbawczą moc Boga oczyszczającą z grzechów, penitent znajduje w tym sakramencie poczucie bezpieczeństwa gwarantowane przez tajemnicę spowiedzi świętej. Pieczęć sakramentalnej spowiedzi zamyka grzeszność człowieka w miłosiernym Sercu Boga i otwiera dla penitenta nowe życie w wolności i radości dziecka Bożego.

Niniejszy artykuł podejmuje kwestię celu tajemnicy spowiedzi sakramentalnej i omawia jej zakres treściowy oraz wskazuje na szczególne przypadki, w których zachowując $\mathrm{w}$ całkowitej tajemnicy wyznanie penitenta, spowiednik może wypowiadać się o jego życiu duchowym dla dobra penitenta i zbudowania społeczności wiernych Kościoła.

\section{CEL I MOTYWY ZACHOWANIA TAJEMNICY SPOWIEDZI}

Tajemnica spowiedzi stoi na straży wielu wartości, które wiążą się z sakramentem pokuty i pojednania. Jej zachowywanie wynika z motywu cnoty religijności, sprawiedliwości i miłości bliźniego oraz wspomaga uniknięcie zgorszenia wiernych ${ }^{1}$. Wyznawanie grzechów kapłanowi w konfesjonale ustanowione przez Chrystusa jako sakrament pokuty ma wymiar sakralny, gdyż ma ono charakter

\footnotetext{
${ }^{1}$ Por. A. Drożdż, Sakrament pojednania z Bogiem i Kościołem. Teologia moralna szczegółowa, Tarnów 1994, s. 128.
} 
osobistego spotkania penitenta z Bogiem i zasługuje na najwyższą miłość i szacunek. Zobowiązanie do zachowania tajemnicy spowiedzi wynika ze względów teologicznych, prawnych i psychologicznych. Ma ona na celu zachowanie świętości sakramentu i szczególności relacji nawiązywanej przez penitenta z Bogiem oraz strzeże dobrego imienia osoby oskarżającej się z grzechów.

Jan Paweł II stwierdził, że kapłan, działając in persona Christi, jest zobowiązany do zachowania $\mathrm{w}$ absolutnej tajemnicy treści wyznanych $\mathrm{w}$ spowiedzi ze względu na szacunek dla uczestniczenia w paschalnym zwycięstwie Chrystusa, które penitent zyskuje w sakramencie pokuty. Kapłan, będąc jedynie szafarzem i pośrednikiem w spotkaniu sakramentalnym w konfesjonale, jest depozytariuszem rzeczywistości, które do niego nie należą, więc nie ma prawa ich ujawniać osobom trzecim². Teologiczny wymiar tajemnicy spowiedzi odnosi się do szczególnego pośrednictwa, jakie szafarz spełnia w imieniu Boga. Święty Tomasz stwierdza, że „kapłan powinien dostosować się do Pana Boga, którego jest sługą. [...] Spowiedź, w której ktoś poddaje się [sądowi] kapłana, jest znakiem wewnętrznego poddania się Panu Bogu, który ukrywa grzechy tego, kto się mu poddaje przez pokutę"3. Naśladowanie Boga, który miłosiernie zachowuje grzech człowieka w tajemnicy, jest pierwszym motywem koniecznego milczenia spowiednika o wyznaniu penitenta.

Dodatkowa motywacja wypływa z ustanowienia Kościoła, który od pierwszych wieków wskazywał na konieczność uszanowania intymności wyznania grzechów. Święty Leon Wielki w Liście do biskupów Kampanii, Samnium i Picenum zwracał uwagę na konieczność wykorzenienia zuchwałej nowości przeciwnej regule apostolskiej, jaką było głośne odczytywanie grzechów. Święty papież przypomina, że wystarczy wyznać swe winy podczas cichej spowiedzi, gdyż najpierw wyznaje się je Bogu, a potem kapłanowi, który oręduje za grzesznika$\mathrm{mi}^{4}$. Trzeba wyraźnie podkreślić, że publiczna pokuta w pierwotnym Kościele dotyczyła publicznie spełnianych aktów zadośćuczynienia za jawne przestępstwa w postaci apostazji, zabójstwa i cudzołóstwa, ale nie polegała na jawnym i otwartym dla osób postronnych wyznawaniu grzechów.

Prawny nakaz zachowywania tajemnicy spowiedzi został wprowadzony przez Sobór Laterański IV, który stwierdził: „Niech kapłan bezwarunkowo wystrzega się, by słowem czy znakiem lub innym sposobem nie zdradził pod jakimś względem grzesznika. [...] Kto by się odważył zdradzić grzech wyznany sobie w sądzie pokuty, ten nie tylko powinien być, jak nakazujemy, złożony z kapłańskiego urzędu, ale także zamknięty w surowym klasztorze dla czynienia pokuty

\footnotetext{
2 Por. Jan Paweł II, Tajemnica spowiedzi świętej. Przemówienie do członków Penitencjarii Apostolskiej, „L'Osservatore Romano” pol. 15:1994 nr 1(183), s. 21.

${ }^{3}$ Tomasz z Akwinu, Suma teologiczna, thum. W.F. Bednarski, t. 30: Sakrament pokuty II, Londyn 1985, s. 95.

${ }^{4}$ Por. Breviarium fidei VII 434.
} 
aż do śmierci"'s. Surowa kara miała odstraszać niefrasobliwych kapłanów od wyjawiania treści spowiedzi i zabezpieczać świętość sakramentu oraz dobre imię grzesznika.

W Kodeksie Prawa Kanonicznego w kanonach 983 i 1388 oraz w Kodeksie Kanonów Kościołów Wschodnich kanon 728 § 1 n. 1 i kanon $1456 \S 1$ wyraźnie wskazano na zakaz ujawniania tego, co było przedmiotem sakramentalnego wyznania. „Tajemnica sakramentalna jest nienaruszalna; dlatego nie wolno spowiednikowi słowami lub w jakikolwiek inny sposób i dla jakiejkolwiek przyczy-

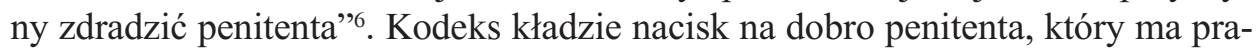
wo do dyskrecji i zachowania dobrego imienia. Chodzi o zapewnienie penitentowi poczucia bezpieczeństwa, które będzie owocowało większym zaufaniem i prowadziło do pełniejszego otwarcia w ramach wyznania grzechów.

Jan Paweł II w przemówieniu do członków Penitencjarii Apostolskiej, wypowiadając się na temat tajemnicy spowiedzi, stwierdził, że ,absolutna powścią-

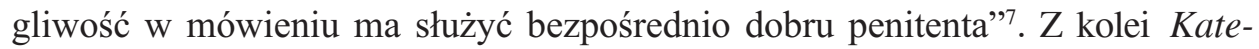
chizm Kościoła katolickiego zwraca uwagę na delikatny charakter spotkania w konfesjonale, które dotyka najintymniejszych tajemnic penitenta, domagając się absolutnego poszanowania dla osób wyznających swoje grzechy i upadki. „Pieczęć sakramentalna” nie dopuszcza żadnych wyjątków i zabrania wykorzystywania wiadomości o życiu penitentów pozyskanych w czasie spowiedzi ${ }^{8}$.

Spowiednik winien unikać zarówno wypowiedzi słownych, jak i zachowań, które przez otwarte nawiązywanie do spowiedzi mogłyby wyrządzić krzywdę penitentowi oraz narazić go na szkodę. Brak dyskrecji kapłana wzbudza niepokój i zgorszenie wśród wiernych oraz powoduje, że przystępowanie do sakramentu pokuty jest odstręczającym i nieprzyjemnym obowiązkiem. Jan Paweł II w następujących słowach zachęcał spowiedników do uszanowania tajemnicy spowiedzi: „Niech kapłani pamiętają, że lekkomyślność i beztroska w tej dziedzinie, nawet jeśli nie przybiera skrajnych form karanych przez prawo, wywołuje zgorszenie, zniechęca wiernych do przystępowania do sakramentu pokuty, przesłania dwutysiącletnią chwalebną tradycję, która miała także swoich męczenników"9.

Ujawnianie swoich słabości, upadków i grzechów w konfesjonale nie jest rzeczą łatwą i wymaga zaufania oraz wiary w zbawcze działanie łaski. Ludzka potrzeba bycia zrozumianym i przyjętym z całą złożonością swoich przeżyć musi napotkać odpowiedni klimat, który zapewniony jest zarówno instytucjonalnie przez zagwarantowanie tajemnicy spowiedzi, jak i osobowo przez dyskretne zachowanie spowiednika. Dyskrecja obejmuje nie tylko zakaz ujawniania przed-

\footnotetext{
${ }^{5}$ Breviarium fidei VII, dz. cyt., 436.

${ }^{6}$ Kodeks prawa kanonicznego, Poznań 1984, kan. $983 \S 1$.

${ }^{7}$ Jan Paweł II, Tajemnica spowiedzi świętej, dz. cyt., s. 21.

${ }^{8}$ Por. Katechizm Kościoła katolickiego, Poznań 1994, nr 1467.

${ }^{9}$ Jan Paweł II, Tajemnica spowiedzi świętej, dz. cyt., s. 21.
} 
miotu wyznania poza konfesjonałem, ale też dotyczy zachowania spowiednika w trakcie spowiedzi. Dlatego nie powinien on pytać o dane osobowe wspólnika w grzechu przeciwko szóstemu przykazaniu Dekalogu i unikać wypytywania o szczegóły grzechów z tego zakresu.

Autorytet urzędu spowiednika winien łączyć się z konkretnym autorytetem osoby znanej i cieszącej się zaufaniem, która swoją postawą ośmiela penitentów do ufnego przedstawienia stanu sumienia. Jakkolwiek każdy szafarz sakramentu pokuty, upoważniony do rozgrzeszania, winien być traktowany jako narzędzie Bożej łaski i przez to obdarzony zaufaniem, to jednak są specjalnie wyposażeni kapłani, który mając szczególny dar pozyskiwania dusz dla Chrystusa, są postrzegani jako charyzmatyczni powiernicy sumień. W postawie spowiednika cieszącego się szczególnym zaufaniem ujawnia się pokora i rozmodlenie oraz łagodność połączona z roztropnością.

Spowiednik bowiem, będąc zobowiązany do dopilnowania integralności wyznania grzechów przez penitenta, musi podczas spowiedzi stawiać pytania, ale winien to czynić mądrze, według określonej hierarchii i kolejności kwestii oraz w odpowiednim czasie, a także posługiwać się właściwym tonem głosu. Komunikując penitentowi życzliwość i chęć pomocy, szafarz pokuty winien dawać poczucie bezpieczeństwa płynące $\mathrm{z}$ właściwego odniesienia do Ojca, który jest Miłosiernym Sędzią zadośćczyniącym za ludzkie grzechy krzyżową śmiercią Syna Bożego. Zarazem swoim doświadczeniem szafarz pojednania pomaga penitentowi odsłonić bolesne wydarzenia życia, które mogą być uzdrowione łaską Odkupiciela $^{10}$.

Osobami, które mogłyby powziąc informacje o wyznaniu grzesznika w sakramentalnej spowiedzi oprócz samego spowiednika, mogą być ponadto thumacz, który zgodnie z kan. 983 § 2 KPK może pośredniczyć w dialogu sakramentalnym, oraz osoby postronne, które przypadkowo z powodu znajdowania się w zbyt bliskiej odległości konfesjonału czy też innego miejsca, np. spowiedzi odbywanej przy łóżku chorego, lub też zbyt głośniej rozmowy w trakcie dialogu penitencjarnego, poznały treść wyznania. Jakkolwiek osoby niebędące szafarzami nie podpadają pod surowe kary kościelne, to jednak są zobowiązani do bezwzględnego milczenia na temat treści usłyszanych $\mathrm{z}$ wyznania dokonanego $\mathrm{w}$ spowiedzi.

\section{ZAKRES TREŚCIOWY TAJEMNICY SPOWIEDZI}

Celem tajemnicy jest ochrona duchowego dobra penitenta, dlatego spowiednik ani żadna inna osoba, która powzięła jakąś informację na temat wyznawanych w spowiedzi grzechów i przewin, nie może ani za życia, ani po śmierci spowiadającego się wyjawiać zarówno samych grzechów przez niego wyzna-

${ }^{10}$ Por. C. Krakowiak, Pokuta i pojednanie w Kościele katolickim, Lublin 2013, s. 42-43. 
nych, jak i okoliczności, które mogłyby wskazać na popełnienie przez niego śmiertelnych grzechów. Chodzi przede wszystkim o unikanie rozpowszechniania informacji, które by mogły stawiać penitenta w złym świetle i sugerować innym jego poważny stan sumienia obciążonego grzechami śmiertelnymi.

Tajemnica sakramentalna może obejmować różne sprawy wprost albo ubocznie. Wprost nakaz milczenia i dyskrecji dotyczy rzeczywistości poznanych w trakcie spowiedzi, niezależnie od tego, czy była to spowiedź ważna lub nieważna, dopełniona lub niedopełniona. Obejmuje to też sprawy, których ujawnienia penitent nie życzyłby sobie. Ubocznie do zakresu tajemnicy spowiedzi przynależy to, co mogłoby wskazać na poszlaki popadania penitenta $\mathrm{w}$ grzechy śmiertelne. Przedmiotem tajemnicy spowiedzi są grzechy śmiertelne w szczególności i powszednie w ogólności oraz okoliczności spowiedzi dotyczące jej zwiększonej częstości odbywania i długości trwania oraz emocjonalnego sposobu przeżywania samego spotkania w konfesjonale. Pod tajemnicę spowiedzi podpada sam fakt udzielenia lub nie rozgrzeszenia oraz wielkość nadanej pokuty sakramentalnej. Spowiednik ponadto nie może nadawać penitentowi pokuty, której publiczny charakter mógłby go narazić na ujawnienie wielkości przewinienia ${ }^{11}$.

Spowiednik nie zdradza tajemnicy spowiedzi, gdyby powiedział, że dany penitent spowiadał się z grzechów powszednich, gdyż żaden człowiek bez szczególnej łaski nie jest w stanie się od nich uchronić. Gdyby jednak szafarz sakramentu wymienił choćby najmniejszy grzech powszedni, już zdradziłby tajemnicę spowiedzi. Istotne jest jednak, by spowiednik powstrzymywał się od tego typu wypowiedzi ${ }^{12}$.

Tajemnicę spowiedzi należy zachować zarówno wobec samego penitenta, jak i wobec innych osób, które przez nieostrożność lub złą wolę rozpowiadającego mogłyby powziąć wiedzę na temat grzechów wyznawanych w spowiedzi. Nie wolno spowiednikowi mówić, wskazywać lub też czynić aluzji dotyczących wyznawanych grzechów ani też zachowywać się w sposób, który sugerowałby negatywne reagowanie na poznane grzechy obciążające penitenta. $Z$ wiadomości pozyskanych w konfesjonale spowiednik nie może korzystać nie tylko ze szkodą dla penitenta, ale też nawet na jego korzyść, przez upominanie i podtrzymywanie go na duchu. Nie może też powoływać się na doświadczenia danego penitenta przy korygowaniu lub ostrzeganiu innych osób.

W zakresie tajemnicy wobec samego penitenta spowiednik nie ma prawa odwoływać się do odbytej spowiedzi ani nawiązywać do treści wyznania w ramach innych spotkań z tymże penitentem. Nie może pytać o postępy w wykorzenianiu grzechów i nabywaniu cnót ani udzielać dodatkowych rad w zakresie ży-

${ }^{11}$ Por. S. Witek, Sakrament pojednania. Podręcznik dla duszpasterzy, Poznań-Warszawa 1979, s. $189-190$.

${ }^{12}$ Por. J.S. Płatek, Sprawowanie sakramentu pokuty i pojednania, Częstochowa 2001, s. 380. 
cia duchowego. Z tej tajemnicy może spowiednika zwolnić sam penitent, który wyraźnie nawiąże do przebiegu spowiedzi i sam pozwoli spowiednikowi na rozmowę na temat swoich problemów moralnych ${ }^{13}$.

Spowiednik, powziąwszy wiedzę o grzechach jakiejś osoby, musi bardzo uważać, by nie dać poznać jej lub innym osobom, tak iż po usłyszeniu wyznania grzechów zmienił się jego stosunek do tej osoby. Oznacza to, że nie może jej traktować bardziej surowo lub ozięble, nie może też podejmować jakiś dodatkowych środków ostrożności, by zabezpieczyć się przed jej ewentualnym nagannym zachowaniem. Nie może też zwracać się do innych osób, by je przestrzec przez swoim penitentem, nawet nie wspominając, że chodzi o treści poznane z sakramentalnej pokuty.

Przedmiotem tajemnicy spowiedzi w sensie ścisłym nie są dobre czyny i cnoty penitenta oraz szczególne dary Boże wyznawane podczas spotkania sakramentalnego. Jednak roztropny spowiednik winien się powstrzymywać od ich ujawniania ${ }^{14}$. Zdarza się, że na potrzeby procesu beatyfikacyjnego lub rozwijania kultu osoby, która zmarła w opinii świętości, spowiednicy wypowiadają się ogólnie o jej szczególnych walorach duchowych. Nie można jednak ujawniać szczegółów spowiedzi ani powoływać się na treść wyznania.

Pod tajemnicę spowiedzi nie podpada sam fakt przystąpienia do spowiedzi, jeśli miała ona miejsce w zwyczajnych okolicznościach danej wspólnoty eklezjalnej. Natomiast jeśli spowiedź była potajemna i penitent chciałby ukryć fakt jej zaistnienia, to spowiednik nie ma prawa ujawniać faktu przystapienia do sakramentu pokuty. Taka sytuacja może dotyczyć dzieci, których rodzice nie mają prawa uzyskać informacji, czy ich dziecko było u spowiedzi w danym dniu. Podobnie też w zamkniętych wspólnotach formacyjnych wychowawcy zewnętrzni nie powinni być informowani przez spowiedników o fakcie częstego przystępowania do spowiedzi przez wychowanków.

Nagłaśniane w mediach przypadki spowiedzi notorycznych grzeszników lub osób przez lata podających się za ateistów i walczących z Kościołem powodują stawianie pytań o możliwość ujawnienia przez kapłana faktu pojednania się z Bogiem $^{15}$. O ile kapłan nie powinien wprost mówić, czy dany penitent otrzymał

${ }^{13}$ Por. A. Derdziuk, Tajemnica spowiedzi wobec penitenta, w: Sakrament pokuty wobec problemów wspótczesności, red. K. Glombik, Opole 2011, s. 241-252.

${ }^{14}$ Por. S. Witek, Sakrament pojednania, dz. cyt., s. 191.

${ }^{15}$ Por. Uroczystości pogrzebowe Józefa Oleksego. http://ekai.pl/diecezje/ordynariat-polowy/x85 705/uroczystosci-pogrzebowe-jozefa-oleksego/[dostęp: 23.05.2015]. Podczas pogrzebu abp L. Głódź, stwierdził, że Oleksy „w przeddzień swej śmierci przyjął sakrament namaszczenia chorych”; Kanclerz Kurii Polowej WP potwierdza fakt udzielenia sakramentów gen. Jaruzelskiemu. http://ekai.pl/ wydarzenia/temat_dnia/x79053/kanclerz-kurii-polowej-wp-potwierdza-fakt-udzielenia-sakramentowgen-jaruzelskiemu/ [dostęp: 23.05.2015] „Po rozmowie z kapelanem, generał w pełni świadomie wyraził wolę pojednania się z Bogiem. Wyspowiadał się, przyjął sakrament namaszczenia chorych i Komunię Świętą"; Tajemnica spowiedzi - czym jest $i$ kiedy bywa naruszana. http://ekai.pl/wydarze nia/x79066/tajemnica-spowiedzi-czym-jest-i-kiedy-bywa-naruszana/ [dostęp: 23.06.2015]. 
rozgrzeszenie, to jednak może wskazać na fakt spowiedzi oraz gotowość penitenta do pojednania się z Bogiem i przyjęcie innych sakramentów. Na ten temat wypowiadają się autorzy podręczników dla spowiedników ${ }^{16}$. Spowiednik winien być ostrożny w ujawnianiu okoliczności spowiedzi, ale może wskazać na chęć naprawienia krzywd. Jeśli jednak penitent chciałby ukryć to przez postronnymi świadkami, winno to być zachowane.

\section{NARUSZENIE TAJEMNICY SPOWIEDZI}

Zdrada tajemnicy spowiedzi może dokonać się bezpośrednio lub pośrednio. Bezpośrednie naruszenie tajemnicy spowiedzi polega na wyjawieniu grzechu i wskazaniu osoby, która się go dopuściła. Nie jest istotne, czy wyjawiający grzechy dodaje, że wie to ze spowiedzi, wystarczy, że wprost mówi o wykroczeniach swojego penitenta, narażając go na zniesławienie lub rzucając negatywne światło na jego postępowanie ${ }^{17}$.

Rozpatrując kwestię od strony świadomości spowiednika, należy stwierdzić, że narusza on tajemnicę, gdy powtarzane treści zna tylko z wysłuchania wyznania penitenta $w$ trakcie spowiedzi. Jeżeli jednak powziął on informacje o nagannym zachowaniu penitenta $z$ innego źródła i opowiada o nich innym osobom, nie zdradza wprost tajemnicy spowiedzi, ale popełnia wielką nieostrożność i wyrządza krzywdę penitentowi oraz naraża na szwank świętość sakramentu przez fakt, że ktoś może uznać to za ujawnianie sakramentalnego wyznania penitenta.

Ścisłym obowiązkiem tajemnicy sakramentalnej nie są objęte sprawy opowiedziane kapłanowi przez kogoś, kto wprawdzie się nie spowiada, ale zwraca się z prośbą o poradę duchową i mówi o swoich problemach moralnych z zaznaczeniem, że prosi o dyskrecję. Kapłan winien zachować jednak sekret naturalny i powierzony, by nie narażać rozmówcy na cierpienie i budować zaufanie do osoby i urzędu szafarza sakramentu pokuty.

Warunkiem istotnym do zaistnienia bezpośredniej zdrady tajemnicy spowiedzi jest znajomość osoby penitenta przez świadków opowiadania o jego grzechach. Wskazanie osoby penitenta może dokonać się wprost przez wymienienie jego imienia lub też podanie okoliczności, które mogą doprowadzić do zidentyfikowania sprawcy grzechu.

16 „Samo podanie wiadomości o odbyciu spowiedzi zasadniczo nie narusza sakramentalnej tajemnicy” - J.S. Płatek, Sprawowanie sakramentu pokuty i pojednania, dz. cyt., s. 381; „Spowiednik może powiedzieć, że człowiek ten już pojednał się z Bogiem, wyznając swoje grzechy” J. Kasztelan, Sprawowanie sakramentu pokuty, Kraków 1993, s. 126; „Pod tajemnicę spowiedzi nie podlega sam fakt przystępowania do spowiedzi, gdyż to jest widoczne dla wszystkich mogących to zaobserwować we wspólnocie Kościoła" - A. Drożdż, Sakrament pojednania z Bogiem i Kościołem, dz. cyt., s. 118.

${ }^{17}$ Por. J. Kasztelan, Sprawowanie sakramentu pokuty, dz. cyt., s. 127. 
Naruszenie tajemnicy spowiedzi w sposób pośredni dokonuje się wtedy, gdy spowiednik opowiada o konkretnym przypadku grzechu bez wyraźnego wskazania sprawcy, ale istnieje niebezpieczeństwo zidentyfikowania grzesznika lub nawet spowodowanie u słuchających tego rodzaju opowieści podejrzenia, że chodzi o konkretną znaną im osobę. Zdrada pośrednia następuje zarówno przez słowa niefrasobliwego spowiednika, jak i przez jego nieodpowiedzialne i nieprzemyślane zachowania rzucające złe światło na penitenta.

Do przypadków naruszenia tajemnicy spowiedzi w sposób pośredni należy wypowiadanie się spowiednika o tym, że spowiedź danego penitenta była trudna, długa i uciążliwa, oraz podawanie informacji, że ktoś się spowiadał z dłuższego okresu życia. Formą zdrady tajemnicy jest ostrzeganie rodziców lub przełożonych, by zwrócili uwagę na pewne zachowania swoich podopiecznych lub też chwalenie jakiegoś penitenta za jego czystość sumienia i porównywanie go z innymi. Spowiednik nie może też wypowiadać się o jakimś małym środowisku, w którym spełniał posługę konfesjonału, że zdarzają się tam poważne wykroczenia. Nieostrożnością i poważnym nadużyciem jest mówienie o pewnych negatywnych zachowaniach określonych grup osób na kazaniu lub w publicznej wypowiedzi z zaznaczeniem, że chodzi o treści usłyszane na spowiedzi.

Zdrada tajemnicy może dokonać się również wówczas, gdy spowiednik nie chce służyć w konfesjonale penitentom, o których wie, że są uciążliwi jako skrupulaci lub też często przychodzą z tymi samymi grzechami. Niedopuszczalne jest głośne upominanie lub odpytywanie penitenta w konfesjonale, które może wzbudzić uwagę osób postronnych. Podobnie negatywnie są oceniane zachowania w postaci głośnego wzdychania oraz reagowania z użyciem podniesionego głosu i niepotrzebnych gestykulacji. Spowiednik nie może też odmówić penitentowi podpisania kartki o odbyciu spowiedzi oraz nie może odmówić Komunii Świętej komuś, kto przed chwilą był u niego u spowiedzi i - nie otrzymawszy rozgrzeszenia - przystępuje do Stołu Pańskiego ${ }^{18}$.

Kościół nakłada surowe kary dla zdradzających tajemnicę spowiedzi. „Spowiednik, który narusza bezpośrednio tajemnicę sakramentalną, podlega ekskomunice wiążącej mocą samego prawa, zastrzeżonej Stolicy Apostolskiej. Gdy zaś narusza ją tylko pośrednio, powinien być ukarany stosownie do ciężkości przestępstwa" 19 . Podobnie surowo mogą być ukarani tłumacze i inne osoby, które powzięly informacje powierzone przez penitenta spowiednikowi w ramach spowiedzi. Szczególny przypadek stanowi podstępne nagrywanie spowiedzi i jej publiczne rozpowszechnianie, które zostało obłożone karą ekskomuniki: „ktokolwiek nagrywa przy pomocy jakiegokolwiek urządzenia technicznego to, co w spowiedzi sakramentalnej, prawdziwej lub symulowanej, własnej lub kogoś in-

\footnotetext{
${ }^{18}$ Por. J.S. Płatek, Sprawowanie sakramentu pokuty i pojednania, dz. cyt., s. 382-383.

${ }^{19}$ Kodeks prawa kanonicznego, Poznań 1984, kan. $1388 \S 1$.
} 
nego, jest mówione przez spowiednika lub przez penitenta, czy upowszechnia to za pośrednictwem środków masowego przekazu, popada w ekskomunikę latae sententiae ${ }^{20}$.

\section{SPOWIEDŹ NA ODLEGŁOŚĆ}

Szczególne sytuacje narażania tajemnicy spowiedzi powodują próby udzielania rozgrzeszania na odległość, zwłaszcza przez wykorzystywanie narzędzi zdalnej komunikacji. Wśród rozważań w tym zakresie podejmuje się kwestię spowiedzi na pewną odległość, spowiedź przez list, telefon oraz za pomocą współczesnych mediów elektronicznych. Chodzi tu zarówno o samo usiłowanie sprawowania sakramentu pokuty, jak i udzielanie odpowiedzi i porad penitentowi, który odwołując się do wcześniejszej spowiedzi usznej, tą drogą prosi o pomoc duchowa.

Jednym z pierwszych przypadków, który był rozpatrywany w tym zakresie, jest kwestia spowiedzi listownej. Kongregacja św. Oficjum na polecenie papieża Klemensa VII 20 czerwca 1602 roku wydała dekret, w którym określiła wyznanie grzechów w liście i prośbę o rozgrzeszenie w tej formie jako fałszywa, lekkomyślną i skandaliczną. Zakazano nie tylko takiego działania uważanego za nieważne i niegodziwe, ale też uznawania dopuszczalności takiej opinii i rozpowszechniania jej drukiem ${ }^{21}$. Wśród argumentów przeciwnych spowiedzi listownej wskazuje się na brak kontaktu osobistego oraz na nierównoczesność aktu żalu spisanego na papierze i jego odczytania przez spowiednika otrzymującego list. W międzyczasie może bowiem zmienić się dyspozycja penitenta i w danym momencie może on już nie żałować swych grzechów, co przy uznawaniu żalu za integralny wymóg sakramentu jest przeszkodą do absolucji ${ }^{22}$.

Ponadto istnieje niebezpieczeństwo nieuprawnionego dostępu do treści listu przez osoby niepowołane, co grozi zdradą tajemnicy spowiedzi i przez to wyklucza ten sposób wyznawania grzechów jako naruszający świętość sakramentu. W pisanym tekście nie zawsze znajdą się też od razu wszystkie elementy wyznania zupełnego, które pozwalałoby szafarzowi uznać je za integralne lub które on by w pełni jednoznacznie zrozumiał. Nie mając możliwości bezpośredniego dialogu z penitentem, nie mógłby dopytać go o sprawy wątpliwe. Jeszcze innym argumentem za odrzuceniem spowiedzi w postaci wyznania grzechów w formie listu jest niebezpieczeństwo, że wierni będą zbyt łatwo interpretowali swo-

\footnotetext{
${ }^{20}$ Kongregacja Nauki Wiary, Dekret o ekskomunice, której podlegaja ujawniajacy treść spowiedzi, w: W trosce o petnię wiary. Dokumenty Kongregacji Nauki Wiary 1966-1994, red. Z. Zimowski, J. Królikowski, Tarnów 1995, s. 324.

${ }^{21}$ Por. M. Pastuszko, Sakrament pokuty i pojednania, Kielce 1999, s. 463.

${ }^{22}$ Por. Z. Sobolewski, Pojednajcie się z Bogiem. Teologicznomoralne i pastoralne aspekty sakramentu pokuty i pojednania, Pelplin 2015, s. 239.
} 
je sytuacje życiowe na rzecz niemożności spowiedzi usznej i zastąpienia jej formą listowną 23 .

Innym zagadnieniem jest spowiedź z pewnej odległości penitenta od spowiednika wynikającej z przeszkód natury fizycznej lub sanitarnej. Wskazując na obecność moralna, która polega na bezpośrednim kontakcie wzrokowym i usznym, dopuszcza się rozgrzeszanie penitenta usytuowanego w odległości pozwalającej na porozumiewanie się bez pośrednictwa innych osób lub mediów. W podręcznikach z zakresu teologii moralnej zorientowanej kanonistycznie przyjmuje się, że obecność moralna zachodzi wówczas, gdy penitent jest oddalony od spowiednika nie więcej niż 12 metrów. Dla ks. Witka 12 metrów oznacza około 20 kroków, zaś dla ks. Pastuszko odległość ta wynosi 12 kroków ${ }^{24}$.

Można zatem rozgrzeszać penitenta, który spada $\mathrm{z}$ dachu lub mostu albo ze statku. Jest możliwe udzielenie absolucji penitentowi przez okno domu lub samochodu. Jeśli ktoś ze względów niezależnych od szafarza i penitenta znajduje się za ścianą lub za drzwiami w innym pomieszczeniu, ale można się wzajemnie porozumieć werbalnie, nawet bez kontaktu wzrokowego, dopuszczalne jest sprawowanie sakramentu pokuty. Nad penitentem odchodzącym od konfesjonału przed uzyskaniem absolucji można odmówić formułę rozgrzeszenia, o ile pozostaje w niedalekiej odległości fizycznej umożliwiającej kontakt wzrokowy. W przypadku grupy ludzi, którzy znajdują się w jednym miejscu i ze względu na niebezpieczeństwo śmierci są rozgrzeszani, spowiednik może wypowiedzieć formułę rozgrzeszenia podniesionym głosem, ale nie jest wymagane, by każdy $\mathrm{z}$ rozgrzeszanych słyszał ją wyraźnie ${ }^{25}$. W przypadku udzielania sakramentu pokuty w obliczu śmierci nie zachodzi niebezpieczeństwo zdrady tajemnicy spowiedzi, bo nie ma też czasu na wyznanie grzechów.

W związku z rozwojem techniki podnosi się niekiedy sprawę rozgrzeszenia przez telefon. Już w 1884 roku Penitencjaria Apostolska została zapytana o możliwość spowiedzi przez telefon w przypadkach nadzwyczajnych, gdy nie ma dostępu do spowiednika w sposób bezpośredni. Odpowiedź brzmiała: Nihil est respondendum ${ }^{26}$. Wśród autorów są wątpliwości, czy spowiedź byłaby ważna. Podnosi się zarzut, że rozmowa telefoniczna nie jest naturalna i ludzka, ale sztuczna i brak jest fizycznej obecności szafarza i penitenta w jednym miejscu. Obaj uczestnicy sakramentu się nie widzą i ponadto mogą zostać podsłuchani, co grozi ujawnieniem tajemnicy spowiedzi. Do natury sakramentalnego spotkania należy bezpośredni kontakt, którego nie zapewnia praesentia fonica umoż-

\footnotetext{
${ }^{23}$ Por. J. Kuźniar, Między niebem a konfesjonatem. Poradnik nie tylko dla tych, którzy się boja spowiedzi, Warszawa 2012, s. 112-115.

${ }^{24}$ Por. M. Pastuszko, Sakrament pokuty i pojednania, dz. cyt., s. 465; S. Witek, Sakrament pojednania, dz. cyt., s. 168.

${ }^{25}$ Por. M. Pastuszko, Sakrament pokuty i pojednania, dz. cyt., s. 465.

${ }^{26}$ Tamże, s. 467.
} 
liwiana przez telefon. Dopuszcza się jednak spowiedź penitenta, który znajdując się za szybą z powodu niebezpieczeństwa zarażenia śmiertelną chorobą, jest bezpośrednio widziany przez spowiednika, a rozmowa odbywa się przez telefon ${ }^{27}$.

Obecnie pojawiają się formy równoczesnego komunikowania się przez Internet, za pomocą komunikatorów, między innymi Skype. Mimo wzajemnego i aktualnego, to jest w czasie rzeczywistym słyszenia się i widzenia za pomoca urządzeń elektronicznych, nie ma możliwości zapewnienia prawdziwej obecności fizycznej i moralnej, która rodzi bliskość i atmosferę osobistego spotkania konieczną do sprawowania sakramentów Kościoła. Dlatego nie dopuszcza się udzielania sakramentalnego rozgrzeszenia tą drogą, także ze względu na możliwość zdrady tajemnicy spowiedzi ${ }^{28}$. Współczesne możliwości kreowania rzeczywistości wirtualnej powodują nie tylko niebezpieczeństwo utraty tożsamości, gdy ktoś się podszywa pod postać ukrytą za awatarem. Pojawia się zagrożenie utraty poczucia rzeczywistości, w której człowiek, grając swoją rolę z pomocą mediów elektronicznych, nie jest w stanie opowiedzieć się za prawdą i dobrem. Jak przypomniała to instrukcja Kościót a Internet

Rzeczywistość wirtualna nie jest zamiennikiem Realnej Obecności Chrystusa w Eucharystii, sakramentalnej rzeczywistości innych sakramentów i współudziału w kulcie sprawowanym w żywej wspólnocie. W Internecie nie ma sakramentów; a nawet doświadczenia religijne, możliwe w nim dzięki łasce Boga, nie są wystarczające $\mathrm{w}$ oderwaniu od współdziałania z innymi wiernymi w świecie rzeczywistym ${ }^{29}$.

W tym kontekście pozostaje jeszcze rozważenie dopuszczalności udzielania porad duchowych przez media elektroniczne, o ile te porady odwołują się do treści poruszanych w sprawowanej wcześniej spowiedzi usznej. Ze względu na „nieszczelność" elektronicznych narzędzi komunikacji, które mogą być podsłuchiwane, podglądane, śledzone i rejestrowane przez różne osoby i instytucje trzeba uznać, że bezpośrednie odwoływanie się do faktu spowiedzi w zakresie podawanych porad, odpowiedzi i zachęt duchowych jest niedopuszczalne i naraża na możliwość zdrady tajemnicy spowiedzi. Kapłan winien zachować szczególną ostrożność i nawet, gdy penitent nieświadomy niebezpieczeństwa zdrady tajemnicy sakramentalnej, zadaje pytania lub dzieli się swoimi wrażeniami na temat spowiedzi, nie powinien nawiązywać do tego, co było przedmiotem wyznania

${ }^{27}$ Por. Z. Sobolewski, Pojednajcie się z Bogiem, dz. cyt., s. 239-240.

${ }^{28}$ Por. T. Zadykowicz, Formacyjna rola mediów. Spowiedź przez Internet?, w: Formacja moralna, formacja sumienia, red. J. Nagórny, T. Zadykowicz, Lublin 2006, s. 210; Z. Sobolewski, Pojednajcie się z Bogiem, dz. cyt., s. 240; J. Kuźniar, Między niebem a konfesjonatem, dz. cyt., s. 117.

${ }^{29}$ Papieska Rada ds. Środków Społecznego Przekazu, Kościół a Internet, http://www.opoka. org.pl/biblioteka/W/WR/rady_pontyfikalne/r_komunik_spol/kosciol_internet_22022002.html [dostęp: 23.05.2015]. 
w sakramencie pokuty. Szafarz pojednania nie powinien też używać słów wskazujących na źródło jego wiedzy i nie powinien tą drogą przypominać choćby pokuty nadanej przez niego w konfesjonale. Może udzielić ogólnych odpowiedzi i wskazać na zwyczajny sposób postępowania w takiej sytuacji.

Tajemnica spowiedzi jest pilnie strzeżona przez Kościół jako narzędzie wspomagające zbawczy dialog człowieka z Bogiem w sakramencie pokuty i pojednania. Jej ustanowienie przed wiekami i obwarowanie surowymi sankcjami kanonicznymi ma na celu zachowanie wrażliwości człowieka na dobro i zło, ale jednocześnie zapewnia stworzenie człowiekowi przyznającemu się do swoich win klimatu absolutnego zaufania i bezpieczeństwa, by mógł otworzyć swe serce na uzdrawiającą łaskę Zbawiciela. Sekret naturalny, wzmocniony sakramentalną pieczęcią, strzeże intymności wyznania i uczy ludzi wzajemnego otwarcia się na siebie. Szczere wyznanie grzechów wspomaga budowanie prawdziwej wspólnoty opartej na odnoszeniu się grzesznych ludzi do miłosierdzia Boga dostępnego w sakramentach Kościoła ${ }^{30}$. Mimo wszechstronnego rozwoju narzędzi komunikacji, nienaruszalne i niezastępowalne pozostaje osobiste sakramentalne spotkanie osób penitenta i spowiednika, które zakorzenione w wierze, dają sobie nawzajem świadectwo wiary, że uczestniczą w zwycięstwie Chrystusa Zmartwychwstałego nad śmiercią, grzechem i Szatanem.

\section{SUMMARY}

The article discusses the secret of confession from the point of view of its serving to spiritual welfare of a penitent and principles which should be respected by confessors. The reason of the secret of confession is good name of a penitent and his sense of security in the confessional and keeping the Canon Law protecting the holiness of this sacrament. The secret of confession includes both sins and circumstances which are the subject of confession in the sacramental encounter. Betrayal of the secret of confession may occur directly or indirectly and in both forms harms a penitent and an ecclesial community. New theological and moral issue is a danger of a breach of secrecy in a confession at a distance, especially with the use of electronic media.

\section{Keywords}

moral theology, sacrament of penance, secret of confession

\section{BIBLIOGRAFIA}

Derdziuk A., Tajemnica spowiedzi wobec penitenta, w: Sakrament pokuty wobec problemów wspótczesności, red. K. Glombik, Opole: RWWTUO 2011, s. 241-252.

Drożdż A., Sakrament pojednania z Bogiem i Kościołem. Teologia moralna szczegółowa, Tarnów: Biblos 1994.

\footnotetext{
${ }^{30}$ Por. Jan Paweł II, Adhortacja apostolska Reconciliatio et paenitentia, Watykan 1984, nr 30.
} 
Jan Paweł II, Adhortacja apostolska Reconciliatio et paenitentia, Watykan: LEV 1984.

Jan Paweł II, Tajemnica spowiedzi świętej. Przemówienie do członków Penitencjarii Apostolskiej, „L'Osservatore Romano” pol. 15:1994 nr 1(183), s. 21-22.

Kasztelan J., Sprawowanie sakramentu pokuty, Kraków: Instytut Teologiczny Księży Misjonarzy 1993.

Katechizm Kościoła katolickiego, Poznań: Pallottinum 1994.

Kodeks prawa kanonicznego, Poznań: Pallottinum 1984.

Kongregacja Nauki Wiary, Dekret o ekskomunice, której podlegaja ujawniajacy treść spowiedzi, w: W trosce o petnię wiary. Dokumenty Kongregacji Nauki Wiary 1966-1994, red. Z. Zimowski, J. Królikowski, Tarnów: Biblos 1995 s. 324.

Krakowiak C., Pokuta i pojednanie w Kościele katolickim, Lublin: Gaudium 2013.

Kuźniar J., Między niebem a konfesjonatem. Poradnik nie tylko dla tych, którzy się boja spowiedzi, Warszawa: IW PAX 2012.

Pastuszko M., Sakrament pokuty i pojednania, Kielce: Wydawnictwo Jedność 1999.

Płatek J.S., Sprawowanie sakramentu pokuty i pojednania, Częstochowa: Wydawnictwo Paulinianum 2001.

Sobolewski Z., Pojednajcie sie z Bogiem. Teologicznomoralne i pastoralne aspekty sakramentu pokuty i pojednania, Pelplin: Bernardinum 2015.

Witek S., Sakrament pojednania. Podręcznik dla duszpasterzy, Poznań-Warszawa: Pallottinum 1979.

Zadykowicz T., Formacyjna rola mediów. Spowiedź przez Internet?, w: Formacja moralna, formacja sumienia, red. J. Nagórny, T. Zadykowicz, Lublin: Wydawnictwo KUL, s. $193-210$.

Andrzej Derdziuk, ur. 1962 r., członek Warszawskiej Prowincji Zakonu Braci Mniejszych Kapucynów. Wyświęcony na prezbitera w 1987 r. przez Jana Pawła II w Lublinie. Profesor doktor habilitowany nauk teologicznych. Pracownik Katedry Teologii Moralnej Społecznej na KUL. Członek Polskiej Komisji Akredytacyjnej. Specjalizuje się w historii teologii moralnej, spowiednictwie oraz teologii życia konsekrowanego. Jest autorem 19 książek i ponad 300 artykułów. Pod jego redakcją ukazało się 18 pozycji książkowych. Jest promotorem 24 doktoratów i 198 magisteriów. 